Agro-Science Journal of Tropical Agriculture, Food, Environment and Extension Volume 18 Number 2 (May 2019) pp. 37-41

ISSN 1119-7455

\title{
ASSESSMENT OF THE USE OF COCOA PRODUCTION MANAGEMENT PRACTICES AMONG COCOA FARMERS IN EKITI STATE, NIGERIA
}

\author{
${ }^{1}$ Awoyemi A.O. and ${ }^{2}$ Aderinoye-Abdulwahab S.A. \\ Department of Agricultural Extension and Rural Development, \\ University of Ilorin, Ilorin Kwara State, Nigeria \\ *Corresponding author’s email: awoyemi.oa@unilorin.edu.ng
}

\begin{abstract}
Cocoa is an important cash crop that contributes significantly to earnings from agriculture in the Nigerian economy. Developing an enterprise in this cash crop requires the use of proper management practices. This study investigated the socioeconomic profile of the cocoa farmers; the types of management practices used among the farmers; and the constraints faced by farmers on cocoa management practices in the study area. Both purposive and simple random techniques, in a four-stage sampling procedure, were used to select one hundred and sixty cocoa farmers for the study. Descriptive statistical tools such as precision counts, frequencies and percentages were used to analyze the data; while Chi-Square analysis was used to test the hypothesis. The results showed that the respondents were predominantly male and married with majority of them having above primary school education, and mean age of 54.10 years. The mean household size was 7 persons, farm size ranged from 1.5 to 23 acres (mean $=7$ acre). Planting of plantain $(M=3.84)$, pruning $(M=3.59)$ and regulated cutting of trees $(M=3.37)$ were ranked high among the management practices used by the farmers. Non-availability of planting material $(M=3.88)$ and problem of pest and diseases $(M=3.74)$ were perceived as the major constraints facing the cocoa management practices. Chi-Square analysis showed that Level of education was significantly related to the management practices used by the cocoa farmers at $r \leq$ 0.01. The study concluded that even though the farmers were in tune with the use of cocoa production management practices, nonetheless, there were some limiting factors such as non-availability of planting materials and pest and diseases affecting the cocoa production in the study area. It was therefore recommended that extension training for farmers should be geared towards pre-planting and post-planting management practices as well as access to adequate planting materials.
\end{abstract}

Key words: use, management practices, cocoa farmers, assessment

\section{INTRODUCTIN}

Cocoa (Theobroma cacao) is an important cash crop in the world economy. In West Africa, cocoa is essentially a smallholder crop; cultivated on 1.2 to 1.5 million farms ranging in size from 1.2 to 2.8 hectares and employing about 10 million people (Padi and Owusu, 2008). It has grown to be a major export crop, accounting for about $37.9 \%$ of agricultural export in 1997 (Oduwole, 2000). Since the discovery of crude oil in Nigeria in the late sixties, there has been a drastic shift from agriculture which was the main hub of Nigeria economy to crude oil production. Cocoa is the main agricultural subsector which contributes immensely to Nigeria's GDP, it also contributes about $15 \%$ to the total Nigerian export in 1970 (Adebile and Amusan, 2011). The relevance of cocoa to most developing economies cannot be overemphasized as cocoa is produced by more than fifty developing countries across Asia, Africa, and Latin America, all of which are in the tropical or sub-tropical areas
(Ogunleye and Oladeji, 2007). Cocoa is mostly grown in fourteen of the thirty-six Nigerian States. The main producing states are located in the South Western part of the country(apart from Cross River, in the South-East), which is the highest cocoa producing region $80 \%$ with most production areas located in Ekiti, Ogun, Ondo, Osun and Edo (FAO, 2013). Cocoa is an important source of raw materials, as well as source of revenue to governments of cocoa producing States (Olowolaju, 2014). Nigeria was ranked second largestex porterofcocoa (Abolagba et al, 2010). Currently, Nigeria is the fourth largest producer after Cote D'ivoire, Ghana and Indonesia contributing $12 \%$ of total world production (ICCO, 2014).The South West is regarded as the cocoa belt of the country, it accounts for $70 \%$ of Nigeria's annual cocoa production (Michael and Nzeka, 2011). Cocoa farmers worldwide depend on cocoa for their livelihood, with an annual world production of three million tonnes (WCF, 2009). 
Cocoa is the main agricultural export in Nigeria though its production accounts for only $0.3 \%$ of the agricultural GDP (IFPRI, 2010). The production of cocoa has suffered a decline and instability in its output owing to problem of poor management practices adopted by cocoa farmers. According to Ekanade and Orimoogunje (2012) in the case of farming whenever the land is opened up for cultivation, the plant-soil equilibrium is disrupted.

It has however, been observed that the cultivation of tree crops in the tropical rain forest region has brought a different dimension to agricultural management practices and environmental conditions. Given that cocoa production is a mainstay of the economy of the tropical rain forest, it becomes pertinent to investigate how farmers are coping with management practices and what effort cocoa farmers are putting to ensure better productivity and also to establish cocoa farmers' sources of extension information and the management practices used. This study assessed the use of management practices in cocoa production among farmers in Ekiti State. The specific objectives were to describe the socio-economic characteristics of the farmers, examine the types of management practices used among cocoa farmers, and identify the constraints faced by cocoa farmers in management practices in the study area. The null hypothesis (Ho) tested was that there is no significant relationship between selected socioeconomic characteristics of the farmers and the type of management practices used.

\section{MATERIALS AND METHODS}

This study was carried out in Ekiti State, Nigeria. The state is located in South Western Nigeria with forest vegetation. The people are mostly farmers cultivating food crops like cassava, yam, maize and tree crops like cocoa and kolanut among others. In four stages shown in Table 1, both purposive and simple random sampling techniques were used to select one hundred and sixty respondents for the study. Firstly, the three ADP zones in Ekiti State were considered, from where one Local Government Area was purposively selected from zones one and three while two LGAs were selected from zone two. These LGAs were purposively selected because they are the major cocoa producers in the zones. The second stage involved a purposive selection of four (4) villages from each of the LGA selected to make a total number of sixteen (16) villages. Again, the selection was purposive due to the fact that cocoa farming is dominant in those areas and cocoa farmers are found in large numbers. The third stage involved a random selection of ten (10) cocoa farmers from each of the sixteen villages to give a total sample size of 160 cocoa farmers. Only one hundred and forty-five pieces of the questionnaire were retrieved from the respondents giving a response rate of $90.6 \%$. This implies that one hundred and fortyfive respondents were used for the data analysis. Data for the study were analyzed through frequency counts and percentages and Chi-Square.

\section{RESULTS AND DISCUSSION}

Socio Economic Characteristics of Respondents Result presented in Table 2 showed that $85.5 \%$ of the cocoa farmers were male while $14.5 \%$ a This implies that cocoa production is mainly dominated by male in the study area. About 28.4 percent of the respondents fell within the age bracket of 41-50 years that is below the mean age which was 54.10 years. A similar finding was reported by Adeogun, Olawoye and Akinbile (2010) who found the mean age of cocoa farmers in Nigeria to be 53years. Thus, a large proportion of the farming populations are adults who are embodiment of indigenous knowledge on good management practices in cocoa production and who have possibly gathered years of experience in cocoa production. The table further shows that majority $(97.2 \%)$ of the respondents were married and could be regarded as responsible positioned to enjoy family labour. It was also shown that the cocoa farmers have large household sizes of mean score 7.50. More than half of the respondents $(76.5 \%)$ were educated above primary education. Education is knowledge acquired in the course of learning at different levels. The result also points that 38 percent of the respondents have been in farming for 21-40 years and 37.3 percent of them have being in farming for 1-20 years while 24.2 percent and 0.7 percent of them have being engaged in farming for 41-60 years and 61 years and above respectively. It implies that majority of the farmers have enough experience about their farming activities and might have acquired overtime the necessary knowledge needed to manage their farming business successfully. The result shows that 45.6 percent of the respondents have a farm size of between 6-10 acre and an average of 7.02 acre. It implies that majority of them were small scale farmers. It should also be noted that the respondents have more than one farm located in different areas in their locality. Majority of the respondents (37.3\%) produce seven to ten kilograms of cocoa annually and earn an average of $\mathrm{N} 42,964.83$ per $\mathrm{kg}$. The average annual net income of the farmers was N301, 887.25.

Types of Cocoa Management Practices used in Cocoa Production

Table 3 reveals that planting of plantain $(M=2.84)$ is a major management practice used by cocoa farmers in the study area. Others includes pruning $(\mathrm{M}=2.59)$, regulated and planned cutting of trees $(\mathrm{M}=2.37)$, slashing and brushing of weeds 
underneath cocoa tree $(\mathrm{M}=2.24)$, minimum tillage $(\mathrm{M}=2.23)$, use of shade trees $(\mathrm{M}=2.12)$, spraying of chemical to control of pest and diseases $(\mathrm{M}=1.77)$. However, planting of economic trees to reduce evaporation rate and mulching $(\mathrm{M}=1.74)$, terracing $(\mathrm{M}=1.72)$ and planting of cover crop $(\mathrm{M}=0.42)$ were of lesser usage in the study area. Note: $\mathrm{SE}=$ Serious Effect, $\mathrm{ME}=$ Moderate Effect, $\mathrm{FE}=\mathrm{Fair}$ Effect, NE=No Effect. The Decision rule: mean score at 2.00, Mean Value above this is regarded as high severity while lower mean is low severity.

Table 1: Sampling Procedure and Sample size of Cocoa Farmers in the Study

\begin{tabular}{llll}
\hline ADP & $\begin{array}{l}\text { Purposive Selection } \\
\text { of LGAs (4) }\end{array}$ & Purposive Selection of villages (16) & $\begin{array}{l}\text { Simple Random selection of Cocoa } \\
\text { farmers }\end{array}$ \\
\hline Ekiti Central (Zone 1) & Ado & $\begin{array}{l}\text { Ago aduloju, aba-ategbado, Emirin, } \\
\text { OkeAgbe }\end{array}$ & 10 farmers each \\
Ekiti South (Zone 2) & Ise-Orun & $\begin{array}{l}\text { Eporo, Alapoto, Kajola, Afolu } \\
\text { Atoka, Abodi, Ojomo, Olotin }\end{array}$ & 10 farmers each \\
& Ikere & Igbona, Ayedu, Iwetin, Arinta & 10 farmers each \\
Ekiti North (Zone 3) & Ikole & & farmers each \\
\hline
\end{tabular}

Table 2: Distribution of the respondents based on their socio-economic characteristics $(n=145)$

\begin{tabular}{|c|c|c|c|}
\hline$x^{2}$ & Frequency & Percentage & Mean \\
\hline \multicolumn{4}{|l|}{ Sex } \\
\hline Male & 124 & 85.5 & \\
\hline Female & 21 & 14.5 & \\
\hline \multicolumn{4}{|l|}{ Age (years) } \\
\hline $20-30$ & 6 & 4.2 & 54.10 \\
\hline $31-40$ & 16 & 11 & \\
\hline $41-50$ & 41 & 28.4 & \\
\hline $51-60$ & 40 & 27.7 & \\
\hline $61-70$ & 26 & 17.9 & \\
\hline Above 71 & 16 & 11.1 & \\
\hline \multicolumn{4}{|l|}{ Marital Status } \\
\hline Single & 4 & 2.8 & \\
\hline Married & 141 & 97.2 & \\
\hline Divorced & 0 & 0 & \\
\hline Widowed & 0 & 0 & \\
\hline \multicolumn{4}{|l|}{ Household size } \\
\hline 3-8 & 109 & 75.3 & 7.50 \\
\hline $9-14$ & 27 & 18.5 & \\
\hline $15-20$ & 9 & 6.2 & \\
\hline \multicolumn{4}{|l|}{ Level of Education } \\
\hline No formal education & 34 & 23.4 & \\
\hline Quranic/Adult education & 6 & 4.1 & \\
\hline Primary education & 35 & 24.1 & \\
\hline Secondary education & 39 & 26.9 & \\
\hline Tertiary education & 31 & 21.4 & \\
\hline \multicolumn{4}{|l|}{ Farming experience } \\
\hline$\leq 20$ & 54 & 37.3 & 30.04 \\
\hline $21-40$ & 55 & 38 & \\
\hline $41-60$ & 35 & 24.2 & \\
\hline 61 above & 1 & 0.7 & \\
\hline \multicolumn{4}{|l|}{ Farm Size(acre) } \\
\hline $1-5$ & 63 & 43.5 & 7.02 \\
\hline $6-10$ & 66 & 45.6 & \\
\hline $11-15$ & 10 & 6.9 & \\
\hline Above 16acre & 6 & 4.1 & \\
\hline \multicolumn{4}{|l|}{ Average kg produced annually } \\
\hline$\leq 150$ & 47 & 32.4 & 9.52 \\
\hline Between 250 & 54 & 37.3 & \\
\hline $375 \mathrm{~kg}$ and above & 22 & 15.2 & \\
\hline \multicolumn{4}{|l|}{ Price of cocoa per kg } \\
\hline $31,000-40,000$ & 21 & 14.6 & $42,964.83$ \\
\hline $41,000-50,000$ & 124 & 85.6 & \\
\hline Average Annual Net income (Naira) & - & - & $301,887.25$ \\
\hline $\begin{array}{l}\text { Average produce multiply by Avera } \\
\text { Average expenses }\end{array}$ & & & \\
\hline
\end{tabular}


Table 4 shows the severity of effects of listed constraints facing the production and management practices of cocoa as indicated by the respondents. Non-availability of planting materials ranked first with weighted mean score of 2.88 , pest and diseases ranked second $(\mathrm{M}=2.74)$, cost of chemical used was rated third $(\mathrm{M}=2.63)$. Inadequate extension information on management practices ranked fourth $(\mathrm{M}=2.54)$, issues of fire outbreak (5th, $\mathrm{M}=2.52$ ), inadequate knowledge on management practices (6th, $M=2.39$ ), lack of financial support from the government (7th, $\mathrm{M}=2.34$ ), high cost of labour (8th, $\mathrm{M}=1.59$ ), Weather, cost of land (9th, $M=1.35$ ) and unpredictable weather conditions (10th, $\mathrm{M}=0.86$ ). Uwagboe et al. (2010) reported that low yield, inconsistent production patterns, disease incidence, pest attack and use of simple farm tools affect cocoa production in Nigeria.

\section{Hypothesis of the Study}

$\mathrm{Ho}_{1}$ : There is no significant relationship between the socio-economic characteristics of cocoa farmers and the management practices used. The result in Table 5 showed there is positive significant relationship between marital status and the management practices used. Also, a significant relationship exists between the level of education, household size of the respondents and the management practices used by the cocoa farmers. This suggests that the level of cocoa management practices increases with the respondent's level of education. This is in accordance with the findings of Olujide and Adeogun (2006) who asserted that education is prerequisite to knowledge of management practices. Constraints Facing the Farmers on Cocoa Management Practices.

Table 3: Distribution of the respondents according to the types of management practices used in Cocoa Production

\begin{tabular}{|c|c|c|c|c|c|c|}
\hline Management Practices & $\mathrm{VO}$ & $\mathrm{O}$ & $\mathrm{R}$ & $\mathrm{N}$ & Mean (std Dev.) & Remark \\
\hline Planting of Plantain & $125(86.2)$ & 17(11.7) & $3(2.1)$ & - & $2.84(0.42)$ & High \\
\hline Pruning/Maintenance & $90(62.1)$ & $51(35.2)$ & $3(2.1)$ & $1(0.7)$ & $2.59(0.57)$ & High \\
\hline $\begin{array}{l}\text { Regulated and planned cutting of } \\
\text { trees }\end{array}$ & 71(49.0) & $61(42.1)$ & $9(6.2)$ & $4(2.8)$ & $2.37(0.73)$ & High \\
\hline $\begin{array}{l}\text { Slashing and brushing of weeds } \\
\text { underneath cocoa trees }\end{array}$ & $54(37.2)$ & $75(51.7)$ & $13(9.0)$ & $3(2.1)$ & $2.24(0.70)$ & High \\
\hline Minimum Tillage & $47(32.4)$ & $86(59.3)$ & $10(6.9)$ & 2(1.4) & $2.23(0.63)$ & High \\
\hline Use of shade trees & $80(55.2)$ & $31(21.4)$ & $5(3.4)$ & $29(20.0)$ & $2.12(1.18)$ & High \\
\hline $\begin{array}{l}\text { Spraying of chemicals to control pest } \\
\text { and diseases }\end{array}$ & $31(21.4)$ & $65(44.8)$ & $33(22.8)$ & $16(11.0)$ & $1.77(0.91)$ & Low \\
\hline $\begin{array}{l}\text { Planting of economic trees to reduce } \\
\text { evaporation rate }\end{array}$ & $52(35.9)$ & $36(24.8)$ & $24(16.6)$ & $33(22.9)$ & 1.74(1.17) & Low \\
\hline Mulching application & 18(12.4) & $91(62.8)$ & $16(11.0)$ & $20(13.8)$ & $1.74(0.85)$ & Low \\
\hline Land Terracing & $37(25.5)$ & $49(33.8)$ & $40(27.6)$ & 19(13.1) & $1.72(0.99)$ & Low \\
\hline Planting of cover crop & $6(4.1)$ & $15(10.3)$ & $13(9.0)$ & 111(76.6) & $0.42(0.84)$ & Low \\
\hline Cumulative Mean Score & & & & & 2.98 & HIGH \\
\hline \multicolumn{7}{|l|}{ Source: Field Survey, (2016) } \\
\hline \multicolumn{7}{|c|}{$\begin{array}{l}\text { Note: } \mathrm{VO}=\mathrm{V} \text { ery Often, } \mathrm{O}=\mathrm{Often}, \mathrm{R}=\text { Rarely, } \mathrm{N}=\text { Never. Note: Decision rule: mean score at } 2.00 \text {, Mean Value above this is regarded as } \\
\text { high usage while lower mean is low usage. }\end{array}$} \\
\hline Constraints & $\mathrm{SE}$ & ME & FE & $\mathrm{NE}$ & Mean (std Dev.) & Rank \\
\hline Non-availability of planting materials & $127(87.6)$ & $18(12.4)$ & - & - & $2.88(0.33)$ & 1 \\
\hline Pest and Diseases & 111(76.6) & $32(22.1)$ & - & $2(1.4)$ & $2.74(0.527)$ & 2 \\
\hline Cost of chemical used. & $97(66.9)$ & $44(30.3)$ & $3(2.1)$ & $1(0.7)$ & $2.63(0.563)$ & 3 \\
\hline $\begin{array}{l}\text { Inadequate extension information on } \\
\text { management practices }\end{array}$ & $96(66.2)$ & $37(25.5)$ & $7(4.8)$ & $5(3.4)$ & $2.54(0.745)$ & 4 \\
\hline Fire outbreak & $82(56.6)$ & $57(39.3)$ & $5(3.4)$ & $1(0.7)$ & $2.52(0.602)$ & 5 \\
\hline $\begin{array}{l}\text { Inadequate knowledge on } \\
\text { management practices }\end{array}$ & $102(70.3)$ & $16(11.0)$ & $8(5.5)$ & 19(13.1) & $2.39(1.068)$ & 6 \\
\hline $\begin{array}{l}\text { Lack of financial support from the } \\
\text { government }\end{array}$ & $58(40)$ & $78(53.8)$ & $9(6.2)$ & - & $2.34(0.592)$ & \\
\hline Cost of labour & $68(46.9)$ & $12(8.3)$ & $4(2.8)$ & $69(47.6)$ & $1.59(1.436)$ & 8 \\
\hline Weather & $48(33.1)$ & $24(16.6)$ & $4(2 \mathrm{~s} .8)$ & $69(47.6)$ & $1.35(1.362)$ & 9 \\
\hline Cost of land allocation & $33(22.8)$ & $3(2.1)$ & $19(13.1)$ & $90(62.1)$ & $0.86(1.242)$ & 10 \\
\hline
\end{tabular}

Source: Field Survey, (2016)

Table 5: Results of the Chi-Square Test analysis of the relationship between socioeconomic characteristics of cocoa farmers and the management practices used

\begin{tabular}{lcccc}
\hline Management Practices & Chi square value & df & Asymp. Sig. (2sided) & Remark \\
\hline Gender & $12.537^{\mathrm{a}}$ & 13 & 0.484 & 0.000 \\
Marital status & $43.816^{\mathrm{a}}$ & 13 & 0.009 & Sot significant \\
Level of education & $78.974^{\mathrm{a}}$ & 52 & 0.000 & Significant \\
Household Size & 90.239 & 8 & Significant \\
\hline
\end{tabular}

**. Correlation is significant at the 0.01 level (2-sided) 


\section{CONCLUSION AND \\ RECOMMENDATIONS}

This study has shown that cocoa farmers in the study area are adults of 53 years on average with a male dominance and the farmers relatively are educated. Cocoa production in the area of study can be said to be low given an output of $250 \mathrm{~kg}$ per annum. It is concluded that the use of cocoa production management practices in Ekiti State is well applauded. This study has therefore been able to demonstrate that the problems of cocoa farmers in the area of study are not those associated with lack of knowledge nor technical know-how of management practices, but more of a constraint related to in-availability of planting materials, pest and diseases and cost of chemicals for management practices in cocoa production. As a result of these findings, the following recommendations were made in order to improve the cocoa production and management practices and consequently improve cocoa productivity and farmers' income in the study area:

1. Farmers should organize a social group that will enable them have opportunities to relearn and

2. Government should establish a mechanism in which farmers can assess credit to purchase viable and improved seedlings of cocoa for planting and also good chemicals in controlling pests and diseases.

3. Cocoa farmers should undertake in weed, pest and disease control exercise to help maintain effective cocoa production through innovation brought to them by extension agents.

4. More extension information should be given on pre-planting and post-planting management practices by the extension agents.

5. Extension agents should not relent in their effort in organizing training, creating awareness and enlightenment on how to boost cultural management practices to increase output and encourage cocoa farmers in the study areas.

\section{REFERENCES}

Abolagba E.O, Onyekwere N.C., Agbonkpolor B.N. and Umar H.Y. (2010). Determinants of Agricultural Exports. J.Hum. Ecol. 27 (3), 181-184

Adebile O.A. and Amusan A.S. (2011). The Non-Oil sector and the Nigeria Economy. A case Study of Cocoa Export Since 1960. International Journal of Asian Social Science. 9 (1), 142-151
Adeogun S.O., Olawoye J.E. and Akinbile L.A. (2010). Information sources to cocoa farmers on cocoa rehabilitation techniques in selected states of Nigeria. Journal media and communication studies 2 (1). 009-015

Ekanade O. and Orimoogunje O.O.I. (2012), Application of Canonical Correlation for Soil-Vegetation Interrelationship in the Cocoa Belt of South Western Nigeria. Resources andEnvironment, 2 (3), 87-92

Food and Agricultural Organization (2013): Analysis of Incentives and Disincentives for Cocoa in Nigeria

Federal Government of Nigeria [FGN] (2007). Sustainable cocoa economy- the Nigerian experience. Being the text of the paper presented as the Nigerian country paper at the African cocoa summit held on 5th September 2007 in Aloro, Ghana.1-9

International Cocoa Organization's (ICCO) (2014). International Cocoa Organization's Annual Report 2011/2012,. 60.

Michael D. and Nzeka U. 2011. Nigeria Cocoa Production Increases. USDA Foreign Agricultural Service, Global Agricultural Information Network

Oduwole O.O. (2000). Sustainable Cocoa Production in Nigeria: Farmers' Perception of Technology Characteristics and Socio-Economic Factors in Adoption Decision. In: Proceedings of the 13th International Cocoa Research Conference Sabah, Malaysia N1147 - 1152.

Ogunleye K.Y. and J.O. Oladeji (2007). Choice of cocoa farmers in Ila local government area of Osun state. Middle-East Journal of Scientific Research, 2 (1), 1420.

Ojediran E.O., Adewumi M.O., Falola A., Ibrahim H.K., Belewu K.Y., Oyedeji O.A. 2018). Analysis of The Determinants of Plantain Supply by Small Holder Farmers In Osun State, Nigeria. Agrosearch, 18 (1), $19-20$

Olowolaju, P. S. 2014. An Assessment of Investment in Technology in Cocoa Processing Industry in Nigeria. Journal of Economics and Sustainable Development 5(10), 182188.

Olujide, M.G and S.O. Adeogun (2006). Assessment of cocoa growers' farm management practices in Ondo State, Nigeria. Spanish Journal of Agricultural Research, 4 (2),

Padi, B. and Owusu, G. (2008). Towards an Integrated Pest Management for Sustainable Cocoa Production in Ghana.

World Cocoa Foundation (2009): Encouraging Sustainable Cocoa Growing 